\title{
A PERFORMANCE ANALYSIS OF REGIONAL BUDGET OF JAYAWIJAYA REGENCY FROM 2010 TO 2014
}

\author{
Didi Yigibalom ${ }^{2}$ \\ received.oxy@gmail.com \\ Ida Ayu Purba Riani ${ }^{3}$ \\ purbariani@gmail.com
}

\begin{abstract}
This study aims to assess performance of Regional Budget (APBD) which includes revenues, spending/expenditures and financing activities of Jayawijaya Government. The data used was the budgeted and realization of Revenue, Spending/Expenditure and Financing activities of Jayawijaya regency from 2010 to 2014. The analysis techniques used was a qualitative approach through various financial ratios. To calculate revenues performance this study employed Variant Analysis (differences of) Budget Revenue, Revenue Growth, Degree of Independence of the region, Regional Reliance to the central government, Degree of Decentralization, Local Tax Effectiveness and Overlay analysis to measure performance of the generated income. Meanwhile to measure expenditure used Variant Analysis (difference) Budgeted Expenditure, Growth of Regional Expenditure, Synchronization of Governmental Spending, Spending Effectiveness and Overlay analysis to measure overall spending/expenditures performance.

Following the analysed data, the study obtained following results: 1) Jayawijaya's revenue performance during 2010 to 2014 based on the overlay analysis was not good. The main caused was due to low degree of the region financial independence, high degree of fiscal dependence for external funding as well as the low degree of fiscal decentralization, 2) Spending/Expenditure Performance of Jayawijaya from 2010 to 2014 was good. This was because of the increasing growth of Jayawijaya's spending/expenditure and the effectiveness of spending/expenditure in Jayawijaya.
\end{abstract}

Keywords: Budget, Revenue, Spending/ Expenditure, Regional Budget

Performance

\section{PENDAHULUAN}

Pemerintah daerah sebagai pihak yang diserahi tugas untuk menjalankan roda pemerintahan, pembangunan, dan pelayanan kepada masyarakat wajib menyampaikan laporan pertanggungiawaban

\footnotetext{
${ }^{2}$ Alumni Mahasiswa Magister Keuangan Daerah Universitas Cenderawasih

${ }^{3}$ Staf Dosen Jurusan Ilmu Ekonomi Fakultas Ekonomi Dan Bisnis Universitas Cenderawasih
} 
keuangan daerahnya untuk dinilai apakah ia berhasil menjalankan tugasya dengan baik atau tidak. Salah satu alat untuk menganalisis kinerja Pemda dalam mengelola keuangan daerahnya adalah dengan melakukan analisis rasio keuangan terhadap APBD yang telah dilaksanakan.

Penggunaan analisis rasio pada sektor publik, khususnya terhadap APBD dan realisasinya belum banyak dilakukan sehingga secara teori belum ada kesepakatan secara bulat mengenai nama dan kaidah peraturannya. Namun, analisis rasio terhadap realisasi APBD harus dilakukan untuk meningkatkan kualitas pengelolaan keuangan daerah. Di samping meningkatkan kuantitas pengelolaan keuangan daerah, analisis rasio terhadap realisasi APBD juga dapat digunakan sebagai alat untuk menilai efektivitas otonomi daerah sebab kebijakan ini yang memberikan keleluasaan bagi Pemerintah daerah untuk mengelola keuangan daerahnya seharusnya bisa meningkatkan kinerja keuangan daerah yang bersangkutan.

Dalam rangka pelaksanaan otonomi daerah dan desentralisasi fiskal, kinerja pemerinah sangat penting untuk dilihat dan diukur. Keberhasilan suatu pemerintah di era otonomi daerah dapat dilihat dari berbagai ukuran kinerja yang telah dicapainya. Pengelolaan anggaran berdasarkan kinerja ini memberikan gambaran yang lebih khusus terkait dengan kemampuan suatu daerah untuk selalu menggali potensi daerah guna meningkatkan anggaran pendapatan yang akan berdampak pada kemampuan pembiayaan penyelenggaran pemerintah dan kegiatan pembangunan daerah. Dalam anggaran berbasis kinerja secara struktur meliputi anggaran pendapatan, anggaran belanja dan pembiayaan. Penekanan pada belanja daerah menjadi titik perhatian terutama sisi belanja membutuhkan kinerja yang lebih baik, transparan dan tepat sasaran.

Menyimak uraian di atas, Kabupaten Jayawijaya merupakan salah satu daerah yang berada di Provinsi Papua yang memiliki kewenangan 
dan tanggungjawab melaksanakan roda pemerintahan, pembangunan dan pelayanan publik yang diikuti degan perimbangan keuangan yang tercermin dalam APBD sebagai intrumen pelaksanaan program-program, fungsi dan urusan pemerintahan berdasarkan asas dan tujuan otonomi daerah sesuai potensi, kondisi dan kebutuhan daerah.

Realisasi Perkembangan realisasi Pendapatan dan Belanja Kabupaten Jayawijaya selama periode 2010-2014 cenderung mengalami peningkatan. Realisasi Pendapatan dearah tahun 2010 tercatat sebesar Rp 653,96 milyar naik menjadi Rp 1.067 trilyun di Tahun 2014, sedangkan realisasi belanja tahun 2010 tercatat sebesar Rp 618,77 milyar yang meningkat menjadi Rp 964,54 milyar di tahun 2014. Dana Perimbangan masih mendominasi penerimaan daerah dibandingkan dengan PAD. Hal ini mengindikasikan masih tingginya ketergantungan fiskal Pemerintah Daerah Kabupaten Jayawijaya terhadap Pemerintah Pusat selama kurun waktu 2010-2014 kendati paket otonomi daerah telah digulirkan. Pada sisi belanja kebutuhan belanja daerah terus mengalami peningkatan dari tahun ke tahun, hal ini merupakan dampak dari kewenangan otonomi daerah dimana pemerintah daerah secara aktif dan lebih leluasa melakukan pembiayaan dalam upaya pengembangan segala bentuk aktifitas progam-program pembangunan di daerah.

Berdasarkan uraian diatas, penelitian ini ingin menganalisis bagaimana kinerja pendapatan dan belanja dearth dengan melihat perkembangan atau pertumbuhan pendapatan daerah selama tahun buku 2010-2014, kemandirian daerah, ketergantungan daerah, derajat desentralisasi fiskal, efektivitas, pertumbuhan belanja, keserasisan belanja serta efektivitas belanja dalam mengelola keuangan daerah pada Kabupaten Jayawijaya.

\section{METODE PENELITIAN}

Kajian ini dilakukan di Kabupaten Jayawijaya dan data yang digunakan adalah data sekunder berupa Realisasi Pendapatan dan 
Belanja Kabupaten Jayawijaya yang bersumber dari LRA Kabupaten Jayawijaya tahun 2010-2014. Teknik analisa data yang digunakan adalah analisa kuantitatif, yaitu data atau informasi berbentuk angka-angka yang dikumpulkan kemudian dianalisis dan ditarik kesimpulan. Adapun alat analisis yang akan digunakan dalam kajian ini adalah:

\section{Analisis Pendapatan}

\section{Analisis Varians Anggaran Pendapatan}

Analisis Varians anggaran pendapatan dilakukan dengan cara menghitung selisih antara realisasi pendapatan dengan yang di anggarkan. Biasanya selisih anggaran sudahdi informasikan dalam laporan realisasi anggaran yang sudah disajikan oleh pemerintah daerah. Informasi selisih anggaran tersebut sangat membantu pengguna laporan dalam memahami dan menganalisis kinerja pendapatan.

\section{Rasio Pertumbuhan Pendapatan}

Untuk mengetahui tingkat pertumbuhan pendapatan, dilakukan dengan mengunakan rumus berikut ini:

$$
\text { Pertumbuhan PAD Tahun } t \frac{P A D \text { Tahun } t-P A D \text { Tahun } t-1}{P A D \text { Tahun } t-1} \times 100 \%
$$

Sumber : Tagel Wirasa (2004: 30)

\section{Analisis Rasio Keuangan}

\section{Rasio Kemandirian Keuangan Daerah}

Tingkat Kemandirian Keuangan daerah adalah ukuran yang menunjukkan kemampuan keuangan pemerintah daerah dalam membiayai sendiri kegiatan pemerintahan, pembangunan, dan pelayanan kepada masyarakat, yang diukur dengan rasio Pendapatan Asli Daerah (PAD) terhadap jumlah bantuan pemerintah pusat dan pinjaman.

$$
\text { Rasio Kemandirian } \frac{\text { Pendaptan Asli Daerah }}{\text { Total Bantuan Pem. Pusat } \backslash \text { Provinsi }} \times 100 \%
$$


Sumber: Mahmudi, $(2007,128)$

Kriteria untuk menetapkan kemandirian keuangan daerah dapat di katagorikan seperti Tabel 1 berikut:

\section{Tabel 1}

Kriteri Penilaian Kemandirian Keuangan Daerah

\begin{tabular}{|c|c|}
\hline $\begin{array}{c}\text { Prosentase PAD terhadap } \\
\text { Dana Perimbangan }\end{array}$ & $\begin{array}{c}\text { Kemandirian Keuangan } \\
\text { Daerah }\end{array}$ \\
\hline $0,00-10.00$ & Sangat Kurang \\
$10,01-20,00$ & Kurang \\
$20,01-30,00$ & Sedang \\
$30,01-40,00$ & Cukup \\
$40,01-50,00$ & Baik \\
$>50,00$ & Sangat Baik \\
Sumber: Tim Litbang Depdagri - Fisipol & UGM, 1991 \\
\hline
\end{tabular}

\section{Rasio Ketergantungan Keuangan Daerah}

Tingkat Ketergantungan Daerah adalah ukuran tingkat kemampuan daerah dalam membiayai aktifitas pembangunan daerah melalui optimalisasi PAD, yang diukur dengan rasio antara PAD dengan total penerimaan Anggaran Pendapatan dan Belanja Daerah (APBD) tanpa subsidi (Dana Perimbangan). Tingkat Ketergantungan Daerah diukur ukuran Dengan Formulasi sebagai berikut:

$$
\text { Rasio Kemandirian } \frac{\text { Total Pendapatan Transfer }}{\text { Total Pendapatan Daerah }} \times 100 \%
$$

Sumber: Mahmudi, $(2007,126)$

Kriteria untuk menetapkan ketergantungan keuangan daerah dapat dikategorikan seperti Tabel 2 berikut:

\section{Tabel 2}

Kriteri Penilaian Ketergantungan Keuangan Daerah

\begin{tabular}{|c|c|}
\hline $\begin{array}{c}\text { Prosentase Belanja Transfer } / \\
\text { Total Penerimaan APBD }\end{array}$ & $\begin{array}{c}\text { Ketergantungan Keuangan } \\
\text { Daerah }\end{array}$ \\
\hline $0,00-10.00$ & Sangant Rendah \\
$10,01-20,00$ & Rendah \\
\hline
\end{tabular}




\begin{tabular}{|c|c|}
\hline $\begin{array}{c}\text { Prosentase Belanja Transfer } / \\
\text { Total Penerimaan APBD }\end{array}$ & $\begin{array}{c}\text { Ketergantungan Keuangan } \\
\text { Daerah }\end{array}$ \\
\hline $20,01-30,00$ & Sedang \\
$30,01-40,00$ & Cukup \\
$40,01-50,00$ & Tinggi \\
$>50,00$ & Sangat Tinggi \\
\hline
\end{tabular}

Sumber: Tim Litbang Depdagri-Fisipol UGM, 1991

\section{Rasio Desentralisasi Fiskal}

Tingkat Desentralisasi Fiskal adalah ukuran untuk menunjukkan tingkat kewenangan dan tanggung jawab yang diberikan pemerintah pusat kepada pemerintah daerah untuk melaksanakan pembangunan. Tingkat desentralisasi fiskal dalam penelitian ini diukur dengan menggunakan rasio PAD terhadap total penerimaan daerah.

Tingkat Desentralisasi Fiskal diukuran. dengan formula untuk mengukur tingkat Desentralisasi Fiskal:

$$
\text { Rasio Derajat Desentralisasi Fiskal } \frac{\text { Total Pendaptan Asli Daerah }}{\text { Total Penerimaan APBD }} \times 100 \%
$$

Sumber: Mahmudi, $(2007,126)$

Kriteria untuk menetapkan Tingkat Desentralisasi daerah dapat dikatagorikan seperti Tabel 3 berikut:

Tabel 3

Kriteria Penilaian Tingkat Desentralisasi Fiskal

\begin{tabular}{|c|c|}
\hline $\begin{array}{c}\text { Prosentase PAD } \\
\text { terhadap TPD }\end{array}$ & $\begin{array}{c}\text { Tingkat Desentralisasi } \\
\text { Fiskal }\end{array}$ \\
\hline $0,00-10.00$ & Sangant kurang \\
$10,01-20,00$ & Kurang \\
$20,01-30,00$ & Sedang \\
$30,01-40,00$ & Cukup \\
$40,01-50,00$ & Baik \\
$>50,00$ & Sangat baik \\
\hline
\end{tabular}

Sumber: Tim Litbang Depdagri - Fisipol UGM,1991 


\section{Rasio efektivitas}

Rasio efektivitas menggambarkan kemampuan pemerintah daerah dalam merealisasikan pendapatan asli daerah yang direncanakan dibandingkan dengan target yang ditetapkan berdasarkan potensi riil daerah (Abdul Halim, 2007:234). Rasio efektivitas dapat diukur dengan formula untuk mengukur tingkat Efektivitas:

$$
\text { Rasio Efektivitas } \frac{\text { Realisasi Penerimaan PAD }}{\text { Target Penerimaan PAD }} \times 100 \%
$$

Sumber: Mahmudi, (2007, 128/129)

Adapun kriteria untuk menetapkan Efektivitas pengelolaan keuangan daerah seperti Tabel 4 berikut ini:

\section{Tabel 4}

\section{Kriteria Penilaian Efektifitas Pengelolaan Keuangan Daerah}

\begin{tabular}{|c|c|}
\hline Prosentase Kinerja Keuangan & Kriteri \\
\hline Diatas $100 \%$ & Sangan efektif \\
$90-100 \%$ & Efektif \\
$80-90 \%$ & Cukup Efektif \\
$60-80 \%$ & Kurang Efektif \\
Kurang dari $60 \%$ & Tidak Efektif \\
\hline
\end{tabular}

Sumber: Depdagri, Kepmendagri No.690.900.327 Tahun 1996

\section{Analisis Keserasian Belanja}

Rasio keserasian belanja menggambarkan bagaimana pemerintah daerah memprioritaskan alokasi dananya pada belanja aparatur daerah dan belanja pelayanan publik secara optimal (Halim, 2007:235). Semakin tinggi persentase dana yang dialokasikan untuk belanja aparatur daerah berarti persentase belanja investasi (belanja pelayanan publik) yang digunakan untuk menyediakan sarana prasarana ekonomi masyarakat cenderung semakin kecil rasio keserasian diformulasikan sebagai berikut: 


\section{Rasio Belanja Tidak Langsung dan Belanja Langsung Terhadap Total Belanja Daerah}

Rasio Belanja Tidak Langsung $\frac{\text { Total Belanja Tidak Langsung }}{\text { Total Belanja Daerah }} \times 100 \%$

$$
\text { Rasio Belanja Langsung } \frac{\text { Total Belanja Langsung }}{\text { Total Belanja Daerah }} \times 100 \%
$$

Sumber : Tim Litbang Depdagri (dalam Dasril Munir: 2004)

\section{Tabel 5}

Kriteria Penilaian Keserasian Belanja

\begin{tabular}{|c|c|}
\hline $\begin{array}{c}\text { Rasio Keserasian Belanja } \\
(\mathbf{\%})\end{array}$ & $\begin{array}{c}\text { Keserasian Belanja } \\
\text { Keuangan Daerah Otonom }\end{array}$ \\
\hline$>80-100$ & Sangat Serasi \\
$>60-80$ & Serasi \\
$>40-60$ & Cukup Serasi \\
$>20-40$ & Kurang Serasi \\
$0-20$ & Tidak Serasi \\
\hline
\end{tabular}

Sumber : Mahsun Moh, 2006

\section{Rasio Efektivitas Belanja}

Untuk menghitung tingkat efektivitas Belanja daerah dapat diformulasikan sebagai berikut :

$$
\text { Rasio Eektivitas Belanja } \frac{\text { Realisasi Belanja }}{\text { Anggaran Belanja }} \times 100 \%
$$

Sumber: Mahmudi $(2007,152)$

Adapun kriteria untuk penilaian efektifitas ditampilakamp ada table berikut ini: 
Table 6

Kriteria Penilaian Efektivitas Belanja Daerah

\begin{tabular}{|c|c|}
\hline PERSENTASE & KRITERIA \\
\hline Diatas $100 \%$ & Sangan efektif \\
$90-100 \%$ & Efektif \\
$80-90 \%$ & Cukup Efektif \\
$60-80 \%$ & Kurang Efektif \\
$\leq 60 \%$ & Tidak Efektif \\
\hline
\end{tabular}

Sumber : Tim Litbang Depdagri - Fisipol UGM, 1991

\section{HASIL ANALISIS DAN PEMBAHASAN}

\section{Analisis Kinerja Pendapatan}

\section{Analisis Varians}

Berdasarkan perhitungan varians pendapatan terlihat bahwa kinerja Pemerintah Kabupaten Jayawijaya menunjukan kinerja cukup baik. Hal tersebut tercermin pada realisasi pendapatan tahun 2010 - 2014 telah melebihi atau melampaui yang ditargetkan, walaupun ditahun 2011 dan 2012 terjadi selisih kurang atau penerimaan anggaran pendapatan Kabupaten Jayawijaya kurang dari anggaran yang ditargetkan.

\section{Tabel 7}

\section{Analisis Varian Anggaran Pendapatan Kabupaten Jayawijaya}

\section{Tahun 2010 - 2014}

\begin{tabular}{|c|c|c|r|}
\hline $\begin{array}{c}\text { Tahun } \\
\text { Anggaran }\end{array}$ & $\begin{array}{c}\text { Anggaran } \\
\text { Pendapatan }\end{array}$ & $\begin{array}{c}\text { Realisasi } \\
\text { Pendapatan }\end{array}$ & $\begin{array}{c}\text { Varian Anggaran } \\
\text { Pendapatan }\end{array}$ \\
\hline 2010 & 648.478 .844 .831 & 653.964 .208 .233 & 5.485 .363 .402 \\
\hline 2011 & 725.400 .568 .486 & 720.823 .592 .660 & -4.576 .975 .826 \\
\hline 2012 & 701.152 .218 .689 & 686.830 .542 .010 & -14.321 .676 .678 \\
\hline 2013 & 966.689 .844 .387 & 970.964 .270 .874 & 4.274 .426 .487 \\
\hline 2014 & 1.063 .992 .100 .488 & 1.067 .154 .645 .682 & 3.162 .545 .194 \\
\hline
\end{tabular}

Sumber : Realisasi APBD Kabupaten Jayawijaya: Data Diolah, 2015

\section{Analisis Pertumbuhan Pendapatan}

Pendapatan daerah Kabupaten Jayawijaya secara umum mengalami kenaikan dari tahun 2010 sampai pada tahun 2014. Peningkatan secara 
dratis terutama terjadi selama dua tahun terakhir yaitu pada tahun 2013 dan tahun 2014. Dimana Pendapatan daerah meningkat pada tahun 2013 dari persentase $8,70 \%$ menjadi $10,67 \%$ di tahun 2014 . Kenaikan persentase pertumbuhan tersebut terjadi seiring dengan kontribusi PAD terhadap total pendapatan daerah yang cenderung meningkat selama periode anggaran tersebut. Tren anggaran pendapatan daerah berkembang cukup lambat dengan rata-rata 6,18\% pertahunnya. Walaupun demikian Pemerintah Daerah Kabupaten Jayawijaya telah berupaya dengan melakukan intensifikasi dan ekstensifikasi sumbersumber PAD yang tercermin dari adanya peningkatan realisasi pos-pos pendapatan daerah seperti Pendapatan Pajak, Pendapatan Retribusi Daerah, Pendapatan Hasil Pengelolaan Kekayaan Daerah yang dipisahkan dan Lain-Lain Pendapatan Daerah yang Sah.

\section{Tabel 8}

Rasio Perkembangan Rencana dan Realisasi Pendapatan Daerah Kabupaten Jayawijaya, 2010-2014

\begin{tabular}{|c|c|c|c|c|}
\hline \multirow{2}{*}{ Tahun } & \multicolumn{3}{|c|}{ Rencana, Realisasi } & \multirow{2}{*}{$\begin{array}{c}\text { Pertumbuhan } \\
\text { (\%) }\end{array}$} \\
\cline { 2 - 5 } & Rencana & Realisasi & Tatal Pendapatan & \\
\hline 2010 & 22.760 .710 .000 & 22.327 .584 .130 & 653.964 .208 .233 & - \\
\hline 2011 & 23.420 .552 .787 & 24.065 .487 .724 & 720.823 .592 .660 & $7.20 \%$ \\
\hline 2012 & 28.057 .560 .211 & 22.316 .934 .446 & 686.830 .542 .010 & $6.86 \%$ \\
\hline 2013 & 28.256 .362 .190 & 30.295 .146 .909 & 970.964 .270 .874 & $8,70 \%$ \\
\hline 2014 & 40.146 .646 .000 & 62.533 .965 .367 & 1.067 .154 .645 .682 & $10,67 \%$ \\
\hline \multicolumn{5}{|c|}{ Rata - rata } \\
\hline
\end{tabular}

Sumber : Realisasi APBD Kabupaten Jayawijaya: Data Diolah, 2015

\section{Analisis Rasio Keuangan}

\section{Rasio Kemandirian}

Rasio kemandirian keuangan daerah menunjukkan kemampuan pemerintah daerah dalah membiayai sendiri kegiatan pemerintahan, pembangunan, dan pelayanan kepada masyarakat yang telah 
membayar pajak dan retribusi sebagai sumber pendapatan yang diperlukan daerah. Kemandirian ini berarti tidak tergantung terhadap sumber dana eksternal. Semakin tinggi rasio kemandirian mengandung arti bahwa tingkat ketergantungan pada bantuan pihak external (terutama pemerintah pusat dan provinsi) semakin berkurang, demikian pula sebaliknya. Rasio kemandirian juga menggambarkan partisipasi masyarakat dalam pembangunan daerah. Semakin tinggi rasio kemandirian, semakin tinggi partisipasi masyarakat dalam membayar pajak dan retribusi daerah yang merupakan komponen utama PAD yang berarti menggambarkan tingkat kesejahteraan masyarakat yang semakin tinggi.

Tabel 9

Perhitungan Kemandirian Keuangan Tahun 2010-2014

\begin{tabular}{|c|c|c|c|}
\hline Tahun & PAD & $\begin{array}{c}\text { Bantuan Pemerintah } \\
\text { Pusat/Provinsi+Pinjaman }\end{array}$ & $\begin{array}{c}\text { Rasio } \\
\text { Kemandirina(\%) }\end{array}$ \\
\hline 2010 & 22.327 .584 .130 & 631.636 .623 .103 & $3,53 \%$ \\
\hline 2011 & 24.065 .487 .724 & 696.758 .104 .936 & $3,45 \%$ \\
\hline 2012 & 22.316 .934 .446 & 664.513 .607 .564 & $3,35 \%$ \\
\hline 2013 & 30.295 .146 .909 & 940.669 .123 .965 & $3,22 \%$ \\
\hline 2014 & 62.533 .965 .367 & 1.004 .620 .680 .315 & $6,22 \%$ \\
\hline \multicolumn{2}{|l|}{ Rata-rata } & $\mathbf{3 , 9 5 \%}$ \\
\hline
\end{tabular}

Sumber : Realisasi APBD Kabupaten Jayawijaya: Data Diolah, 2015

Dari tabel perhitungan diatas, dapat dilihat bahwa dari rasio persentase pada tahun 2010-2014 kemandirian daerah cenderung mengalami penurunan, kecuali tahun 2014 persentase kemandirian keuangan mengalami kenaikan sebesar $6 \%$. Kemandirian keuangan Pemerintah Kabupaten Jayawijaya pada tahun 2010 adalah 3\%. Dimana realisasi PAD hanya dapat memberikan kontribusi terhadap pendapatan daerah sebesar 3\%, demikian juga pada tahun 2011-2013 rata-rata kemadirian tetap pada posisi $3 \%$ seperti tahun sebelumnya. Kinerja pemerintah Kabupaten Jayawijaya dari segi kemandirian keuangan, tetap belum tercapai selama 5 tahun periode penilaian. Tetapi apabila dilihat dari trennya persentase rasio kemandirian keuangan daerah tertinggi 
ditunjukkan pada tahun 2014 yaitu 6\%, ini artinya bahwa Pemerintah Kabupaten Jayawijaya masih belum mandiri, karena dalam membiayai sendiri kegiatan pemerintahan, pembangunan, dan pelayanan kepada masyarakat masih tergantung pada bantuan pemerintah pusat/ Provinsi dan lain-lain pendapatan yang sah.

Secara umum kinerja kemandirian daerah Kabupaten Jayawijaya dilihat dari rata-rata rasio berdasarkan Kriteria penilaian keuangan yang dikeluarkan Tim Litbang Depdagri-Fisipol UGM, 1991 dapat dikatakan kemandirian "Sangat Kurang". Untuk itu diperlukan usaha pemerintah Kabupaten Jayawijaya yang lebih besar dalam hal melakukan intensifikasi dan ekstesifikasi sumber-sumber PAD untuk mengurangi ketergantungan atas sumber dana eksternal serta meminta kewenangan untuk mengelolah sumber-sumber pendapatan lain yang sampai saat ini masih dikelolah oleh pemerintah pusat dan provinsi.

\section{Rasio Ketergantungan Daerah}

Semakin tinggi rasio ketergantungan ini semakin besar pula tingkat ketergantungan pemda pada pemerintah pusat maupun provinsi. Dana dari pihak eksternal yang dimaksud adalah dana perimbangan atau dan transfer dari pemerintah pusat maupun provinsi, yang diantaranya berupa dana bagi hasil pajak, DAU, DAK, dsb yang termasuk dana dari pemerintah pusat maupun propinsi. Pengertian dari dana perimbangan sendiri atau menurut UU terbaru disebut dengan dan transfer adalah dana yang bersumber dari penerimaan Anggaran Pendapatan dan Belanja Negara (APBN) yang dialokasikan kepeda daerah untuk membiayai kebutuhan daerah dalam rangka pelaksanaan desentralisasi. 
Tabel 10

Rasio Ketergantungan Keuangan Daerah Tahun 2010 - 2014

\begin{tabular}{|c|c|c|c|}
\hline Tahun & $\begin{array}{c}\text { Total Pendaptan } \\
\text { Daerah }\end{array}$ & $\begin{array}{c}\text { Pendapatan } \\
\text { Transfer }\end{array}$ & $\begin{array}{c}\text { Rasio } \\
\text { Ketergantungan } \\
\text { (\%) }\end{array}$ \\
\hline $\mathbf{2 0 1 0}$ & 653.964 .208 .233 & 631.636 .623 .103 & $96,58 \%$ \\
\hline $\mathbf{2 0 1 1}$ & 720.823 .592 .660 & 696.758 .104 .936 & $96,66 \%$ \\
\hline $\mathbf{2 0 1 2}$ & 686.830 .542 .010 & 664.513 .607 .564 & $96,75 \%$ \\
\hline $\mathbf{2 0 1 3}$ & 970.964 .270 .874 & 940.669 .123 .965 & $96,87 \%$ \\
\hline $\mathbf{2 0 1 4}$ & 1.067 .154 .645 .682 & 1.004 .620 .680 .315 & $94,14 \%$ \\
\hline \multicolumn{2}{|l|}{ Rata-rata } & $\mathbf{9 6 , 2 0 \%}$ \\
\hline
\end{tabular}

Sumber : Realisasi APBD Kabupaten Jayawijaya: Data Diolah, 2015

Rara-rata ketergantungan keuangan Pemerintah Daerah Kabupaten Jayawijaya selama periode 2010-2014 mencapai 96,20\%. Tingkat ketergantungan keuangan tertinggi terjadi pada tahun anggaran 2010-2013 dengan nilai persentase sebesar $96 \%$, kemudian pada tahun 2014 ketergantungan kembali mengalami penunurunan dengan persentase $94,14 \%$ dari tahun-tahun sebelumnya.

Dari tahun 2010-2014 pendapatan transfer yang mendominasi adalah DAU (Dana Alokasi Umum) dimana memang dana ini adalah dana yang dialokasikan dengan tujuan pemerataan kemampuan keuangan antar daerah untuk membiayai kebutuhan pengeluarannya dalam rangka pelaksanaan desentraliasi. Melihat dari analisis rasio ketergantungan, Pemerintah Kabupaten Jayawijaya dapat dikatakan masih tergantung dengan pihak eksternal, karena dilihat prosentase kontribusi pendapatan transfer mendominasi total pendapatan, semua persentasenya menunjukkan lebih dari setengah atau $50 \%$. Namun dilihat dari trennnya, pada satu tahun terakhit telah mengalami perbaikan ketergantungan terhadap pendapatan transfer sudah menurun.

Dengan demikian dapat dikatan bahwa ketergantungan pemerintah kabupaten jayawijaya selama perioden anggaran 2010-2014 berdasarkan kriteria penilaian ketergantungan yang dikeluarkan oleh Tim 
Litbang Depdagri-Fisipol UGM, 1991, dinilai "Sangat Tinggi" dengan rata-rata persentase $94,14 \%$.

\section{Rasio Derajat Desentralisasi}

Derajat Desentralisasi menyatakan besaranya kontribusi PAD terhadap pendapatan daerah. Semakin tinggi kontribusi PAD maka semakin tinggi kemampuan daerah dalam penyelenggaraan desentralisasi. PAD yang dipandang sebagai elemen pendapatan selaku indikator keberhasilan desentralisasi pada pemerintah daerah, sudah selayaknya kalau kontribusinya terhadap pendapatan besar. Kontribusi PAD yang tinggi terhadap total pendapatan daerah ditunjukkan dengan persentase yang tinggi.

Tabel 11

Perhitungan Derajat Desentralisasi Kabupaten Jayawijaya

Tahun 2010 - 2014

\begin{tabular}{|c|c|c|c|}
\hline Tahun & PAD & $\begin{array}{c}\text { Total } \\
\text { Pendapatan } \\
\text { Daerah }\end{array}$ & $\begin{array}{c}\text { Rasio Derajat } \\
\text { Desentralisasi(\%) }\end{array}$ \\
\hline $\mathbf{2 0 1 0}$ & 22.327 .584 .130 & 653.964 .208 .233 & $3,41 \%$ \\
\hline $\mathbf{2 0 1 1}$ & 24.065 .487 .724 & 720.823 .592 .660 & $3,33 \%$ \\
\hline $\mathbf{2 0 1 2}$ & 22.316 .934 .446 & 686.830 .542 .010 & $3,32 \%$ \\
\hline $\mathbf{2 0 1 3}$ & 30.295 .146 .909 & 970.964 .270 .874 & $3,12 \%$ \\
\hline $\mathbf{2 0 1 4}$ & 62.533 .965 .367 & 1.067 .154 .645 .682 & $5,85 \%$ \\
\hline \multicolumn{2}{|l|}{ Rata-Rata } & $\mathbf{3 , 8 1} \%$ \\
\hline
\end{tabular}

Sumber : Realisasi APBD Kabupaten Jayawijaya: Data Diolah, 2015

Dari tabel perhitungan diatas, terlihat bahwa desentralisasi fiscal atau persentase kontribusi PAD terhadap total pendapatan yaitu sebesar $5,85 \%$, berdasarkan Kriteria Penilaian Tingkat Desentralisasi Fiskal yang dikeluarkan oleh Tim Litbang Depdagri-Fisipol UGM, 1991 ini berarti kemampuan pemerintah dalam menyelenggarakan desentralisasi selama periode ini adalah "Sangat Kurang” karena kontribusi PAD terhadap total penerimaan daerah Kabupaten Jayawijaya masih kurang atau dengan kata lain persentase pendapatan transfer masih mendominasi total penerimaan daerah. Pada tahun 2014 tingkat 
desentralisasi Kabupaten Jayawijaya terjadi kenaikan, dimana persentase PAD terlihat naik yang juga diiringi oleh kenaikan total Pendapatan Daerah. Pada tahun ini tingkat desentralisasi mengalami kenaikan yang drastis dengan angka 5,85\% ini artinya kemampuan desentralisasi meningkat.

Secara umum dapat dikatakan derajad desentralisasi Kabupaten Jayawijaya dilihat dari rata-rata yaitu $3,81 \%$ berdasarkan Kriteria Penilaian Tingkat Desentralisasi Fiskal yang dikeluarkan oleh Tim Litbang DepdagriFisipol UGM, 1991 "Sangat Kurang”.

Sebenarnya rasio desentraliasi ini mendukung rasio kemandirian, hanya saja di sini kita dapat lebih mengetahui ukuran sebenaranya seberapa besar PAD memberikan kontribusi pada total pendapatan daerah. Untuk itu kedepannya Pemerintah Kabupaten Jayawijaya harus lebih berupaya untuk meningkatkan PAD nya dengan melakukan intensifikasi dan ekstensifikasi sumber-sumber menerimaan PAD dengan menggali baru ataupun dengan mengembangkan potensi-potensi ril yang sudah ada.

\section{Efektivitas Pajak Daerah}

Rasio efektivitas menggambarkan kemampuan pemerintah daerah dalam merealisasikan pendapatan asli daerah yang direncanakan dibandingkan dengan target yang ditetapkan berdasarkan potensi riil daerah. Menurut rasio ini pajak daerah dianggap sangat efektif apabila persentasenya mencapai angka 1 atau $100 \%$.

Tabel 12

Perhitungan Efetivitas Pajak Daerah Kabupaten Jayawijaya Tahun 2010 - 2014

\begin{tabular}{|c|c|c|c|}
\hline \multirow{2}{*}{ Tahun } & \multicolumn{2}{|c|}{ Pajak Daerah } & \multirow{2}{*}{$\begin{array}{c}\text { Rasio } \\
\text { Efektivitas(\%) }\end{array}$} \\
\cline { 2 - 3 } & Rencana & Realisasi & 59,67 \\
\hline 2010 & 3.079 .903 .000 & 1.837 .844 .291 & 111,84 \\
\hline 2011 & 2.364 .754 .797 & 2.644 .844 .681 & 110 \\
\hline
\end{tabular}




\begin{tabular}{|c|c|c|c|}
\hline \multirow{2}{*}{ Tahun } & \multicolumn{2}{|c|}{ Pajak Daerah } & \multirow{2}{*}{$\begin{array}{c}\text { Rasio } \\
\text { Efektivitas(\%) }\end{array}$} \\
\cline { 2 - 3 } & Rencana & Realisasi & 89,58 \\
\hline 2012 & 4.001 .449 .632 & 3.584 .793 .761 & 162,77 \\
\hline 2013 & 3.985 .579 .171 & 6.487 .545 .764 & 251,04 \\
\hline 2014 & 4.435 .000 .000 & 11.133 .886 .935 & $\mathbf{1 3 4 , 9 8}$ \\
\hline \multicolumn{2}{|l}{ Rata-Rata } \\
\hline
\end{tabular}

Sumber : Realisasi APBD Kabupaten Jayawijaya: Data Diolah, 2015

Dari tabel perhitungan di atas Efektivitas pajak daerah mencapai puncaknya pada tahun 2014, di mana pada periode penelitian ini efektivitasnya cenderung mengalami kenaikan, kecuali pada tahun 2010 dan tahun 2012 yang mengalami penurunan setelah tahun 2011. Pada tahun 2010 pajak daerah terealisasi sebesar 59,67\% kemudian meningkat pada tahun 2011 pada angka $111,84 \%$ dikarenakan adanya kenaikan dalam realisasi perolehan dan target pajak daerah, jadi kinerja Pemerintah Kabupaten Jayawijaya pada tahun ini berkembang, karena pencapaian target lebih tinggi pada anggaran yang direncanakan. Pada tahun 2012 rasio efektivitas pajak daerah mengalami penurunan bibawa $100 \%$ denga persentase $89,84 \%$, karena kemampuan Pemerintah Kabupaten Jayawijaya dalam merealisasikan pajak menurun. Pada tahun 2013 dan tahun 2014 rasionya mengalami kenaikan dan semakin tinggi dibandingan tahun-tahun sebelumnya bahkan kenaikannya drastis yaitu mencapai angka $251 \%$, sehingga secaraumum kinerja efektivitas Pajak daerah Pemerintah Kabupaten Jayawijaya berdasarkan criteria penilaian efektivitas pajak daerah yang dikeluarkan oleh Depdagri, Kepmendagri No.690.900.327 Tahun 1996, kinerja Pemerintah Kabupaten Jayawijaya dikatakan "Sangat Efektif".

Dengan demikian diharapkan Pemerintah Kabupaten Jayawijaya dapat mempertahankan atau terus berusaha meningkatkan keefektifan di bidang perolehan pajak daerah. Usaha untuk mempertahankan keefektifan tersebut dapat dilakukan dengan mengoptimalkan pemungutan, selain itu juga mengoptimalkan pengelolaan, agar keduanya dapat berjalan seperti apa yang direncanakan. 


\section{Analisis overlay Pendapatan}

Analisis ini digunakan untuk mengkomparasi dan mengukur skor kinerja berdasarkan rasio-rasio pendapatan yang telah diukur sebelumnya. Skor ditetapkan berdasarkan penjumlahan tanda $(+)$ dan $\quad(-$ ) dari masing-masing indikator rasio yang telah diukur dahulu.

Jika skor kinerja bertanda (+) berarti kinerja pendapatan dikatakan baik. Sebailknya jika skor kinerja bertanda (-) dapat dikatakan kinerja Pendapatan tidak baik.

Tabel 13

Analisis Kinerja Pendapatan Kabupaten Jayawijaya Tahun 2010 2014 Berdasarkan Analisis Overlay

\begin{tabular}{|c|c|c|c|c|c|c|c|c|}
\hline \multicolumn{9}{|c|}{ Uraian } \\
\hline $\begin{array}{c}\text { Tahun } \\
\text { Anggaran }\end{array}$ & $\begin{array}{l}\text { Analisis } \\
\text { Varians }\end{array}$ & $\begin{array}{c}\text { Analisis } \\
\text { Pertumbuhan }\end{array}$ & $\begin{array}{c}\text { Analisis } \\
\text { Kemandirian }\end{array}$ & $\begin{array}{c}\text { Analisis } \\
\text { Ketergantungan }\end{array}$ & $\begin{array}{c}\text { Analisi } \\
\text { Desentralisasi }\end{array}$ & $\begin{array}{c}\text { Analisis } \\
\text { Efektivitas }\end{array}$ & Skor & $\begin{array}{l}\text { Kriteria } \\
\text { Kinerja }\end{array}$ \\
\hline 2010 & + & & -- & -- & $-\ldots$ & -- & -11 & Tidak Baik \\
\hline 2011 & - & + & $-\ldots$ &.- & $-\ldots$ & ++ & -7 & Tidak Baik \\
\hline 2012 & - & + & -- & -- & -- & 0 & -9 & Tidak Baik \\
\hline 2013 & + & + &.- & -- & -- & ++ & -5 & Tidak Baik \\
\hline 2014 & + & + & $-\ldots$ &.- & $-\ldots$ & ++ & -5 & Tidak Baik \\
\hline
\end{tabular}

Sumber : Realisasi APBD Kabupaten Jayawijaya: Data Diolah, 2015

Dari analisis tabel diatas, kinerja pendapatan daerah Kabupaten Jayawijaya sepanjang tahun 2010 - 2014 berdasarkan analisis overlay dapat dikatakan "Tidak Baik". Hasil penelitian ini tidak sama atau dengan kata lain menolak hipotesa sementara sebelumnya yang menyatakan, kinerja pendapatan daerah Kabupaten Jayawijaya dikategorikan cukup baik.

Adapun faktor permasalahan yang dihadapi Pemerintah Daerah Kabupaten Jayawijaya setiap tahun adalah faktor kemandirian keuangan daerahnya yang dikategorikan masih sangat kurang, faktor ketergantungan fiskal daerahnya yang digolongkan masih sangat tinggi terhadap dana eksternal dan permasalahan selanjutnya adalah faktor derajat desentralisasi fiskal daerah yang dikategorikan masih sangat kurang. 


\section{Analisis Kinerja Belanja}

\section{Analisis Varian Belanja}

Analisis Varian Belanja digunakan untuk mengukur perbedaan antara belanja yang dianggarkan dan realisasi belanja yang telah dimanfaatkan oleh Pemerintah termasuk Pemerintah Kabupaten Jayawijaya. Analsis Varian Belanja diukur dengan melihat selisih antara pemanfaatan belanja secara realisasi dengan belanja yang dianggarkan. Semakin kecil selisih antara anggaran dan realisasi belanja maka Pemerintah Kabupaten Jayawijaya telah memanfaatkan APBD khususnya Belanja Daerah dengan baik.

Tabel 14

Varians Belanja Daerah Kabupaten Jayawijaya Tahun 2010 - 2014

\begin{tabular}{|c|c|c|c|}
\hline \multirow{2}{*}{$\begin{array}{c}\text { Tahun } \\
\text { Anggaran }\end{array}$} & $\begin{array}{c}|c| \\
\text { Anggaran } \\
\text { Belanja }\end{array}$ & $\begin{array}{c}\text { Realisasi } \\
\text { Belanja }\end{array}$ & Varians Belanja \\
\cline { 2 - 4 } & 657.025 .555 .829 & 618.775 .520 .677 & 38.250 .035 .152 \\
\hline 2010 & 759.583 .804 .386 & 728.794 .684 .703 & 30.789 .119 .683 \\
\hline 2011 & 738.567 .678 .369 & 686.862 .642 .569 & 51.705 .035 .800 \\
\hline 2012 & 1.048 .936 .074 .075 & 954.558 .203 .785 & 94.377 .870 .290 \\
\hline 2013 & 1.064 .481 .116 .328 & 964.538 .017 .453 & 99.943 .098 .875 \\
\hline 2014 &
\end{tabular}

Sumber : Realisasi APBD Kabupaten Jayawijaya: Data Diolah, 2015

Dari tabel perhitungan tersebut di atas dapat diketahui bahwa selama tahun 2010 sampai dengan tahun 2014 Varian Belanja menunjukkan angka yang cukup baik, dengan selisih/varian yang mendekati sama dari tahun ke tahun. Hal ini berarti bahwa Pemerintah Daerah Kabupaten Jayawijaya telah memanfaatkan anggaran belanja dengan baik dimana realisasi penfanfaatan belanja yang telah dilaksanakan oleh Pemerintah Kabupaten Jayawijaya lebih kecil dari anggaran yang telah direncanakan. Dengan demikian dapat dikatakan dilihat dari Analisis Varian Belanja Pemerintah Kabupaten Jayawijaya telah memanfaatkan APBD dengan baik. 


\section{Analisis Pertumbuhan Belanja}

Pertumbuhan belanja daerah Kabupaten Jayawijaya selama tahun 2010-2014 cenderung mengalami peningkatan. Pada tahun 2010 terjadi pertumbuhan belanja daerah sebesar $7,28 \%$. Kemudian psds tahun 2011 pertumbuhan belanja Daerah Kabupaten Jayawijaya kembali mengalami penurunan sebesar $6,86 \%$ daritahun sebelumnya. Pada tahun ini, kinerja Pemerintah Daerah Kabupaten Jayawijaya kurang baik, Karen dalam merealisasikan anggaran belanjanya telah melebihi atau melampau anggaran belanja yang direncanakan. Pada tahun selanjutnya yaitu 2013-2014 terjadi kenaikan kembali pertumbuhan belanja daerah pada tahun 2013 dengan persentase 9,54\% dan pada tahun 2014 dengan persentase pertumbuhan 9,64 dari tahun sebelumya. Dengan demikian, kinerja anggaran belanja Pemerintah Daerah Kabupaten Jayawijaya dilihat dari tren rata-rata pertumbuhan dikatakan baik, karena dalam merealisasikan anggaran belanja daerah lebih rendah dari yang dianggarkan.

Tabel 15

Pertumbuhan Belanja Tahun 2010 - 2014

\begin{tabular}{|c|c|c|}
\hline Tahun & $\begin{array}{c}\text { Belanja Daerah } \\
\text { (RP) }\end{array}$ & $\begin{array}{c}\text { Tingkat } \\
\text { Pertumbuhan (\%) }\end{array}$ \\
\hline 2010 & 618.775 .520 .677 & - \\
\hline 2011 & 728.794 .684 .703 & $7.28 \%$ \\
\hline 2012 & 686.862 .642 .569 & $6.86 \%$ \\
\hline 2013 & 954.558 .203 .785 & $9.54 \%$ \\
\hline 2014 & 964.538 .017 .453 & $9.64 \%$ \\
\hline \multicolumn{2}{|c|}{ Rata Rata } & $8.33 \%$ \\
\hline
\end{tabular}

Sumber : Realisasi APBD Kabupaten Jayawijaya: Data Diolah, 2015

\section{Analisis Keserasian Belanja}

\section{Rasio Aktivitas/ Keserasian}

Analisis keserasian pada belanja bermanfaat untuk mengetahui keseimbangan antar belanja. Rasio keserasian ini melihat keserasian antara Rasio Belanja Tidak Langsung dan Rasio Belanja Langsung. Rasio ini menggambarkan bagaimana pemerintah daerah 
memprioritaskan alokasi dananya pada belanja tidak langsung dan belanja langsung secara optimal. Semakin tinggi persentase dana yang dialokasikan untuk belanja tidak langsung berarti persentase belanja langsung yang digunakan untuk menyediakan sarana dan prasarana ekonomi masyarakat cenderung semakin kecil. Perhatikan Tabel 16 dan 17 berikut ini.

Dari tabel 16, tren pergerakan Belanja Tidak Langsung dan belanja Langsung Pemerintah Kabupaten Jayawijaya tahun 2010-2014 terus mengalami kenaikan, baik Belanja Tidak Langsung maupun Belanja Langsung.

Table 16

Realisasi Belanja Tidak Langsung Dan Belanja Langsung Kabupaten Jayawijaya Tahun 2010 - 2014

\begin{tabular}{|l|c|c|r|r|r|}
\hline Belanja Tidak Langsung & $\mathbf{2 0 1 0}$ & $\mathbf{2 0 1 1}$ & $\mathbf{2 0 1 2}$ & \multicolumn{1}{|c|}{$\mathbf{2 0 1 3}$} & $\mathbf{2 0 1 4}$ \\
\hline a. Belanja Pegawai & 180.509 .729 .688 & 238.075 .384 .996 & $316.850 .477 .303,00$ & $325,377,682,032$ & $326,292,430,528$ \\
\hline b. Belanja Bunga & $655,200,000$ & 0 & 0 & $395,322,000$ & - \\
\hline c. Belanja Subsidi & - & $1,500,000,000$ & $13,602,080,000.00$ & $15,396,194,513$ & 10.604 .400 .000 \\
\hline d. Belanja Hibah & 41.580 .337 .821 & $39,408,182,400$ & $38.126 .787 .411,00$ & $103,112,445,873$ & $83,885,138,000$ \\
\hline e. Belanja Bantuan Sosial & $26,789,782,349$ & $41,077,044,547$ & $21.370 .750 .000,00$ & $2,637,500,000$ & $2,394,400,000$ \\
\hline f. Belanja Bagi Hasil & - & - & - & - & - \\
\hline g. Belanja Keuangan & $10,054,650,000$ & $22,120,800,000$ & $7.210 .000 .000,00$ & $53,790,250,000$ & 42.620 .000 .000 \\
\hline h. Belanja Tidak Terduga & 11.542 .868 .000 & $4,158,946,000$ & $3.010 .000 .000,00$ & $157,480,605$ & $2,999,999,442$ \\
\hline Jumlah Belanja Tidak Langsung & $\mathbf{2 7 1 , 1 3 2 , 5 6 7 , 8 5 8}$ & $\mathbf{3 4 6 , 3 4 0 , 3 5 7 , 9 4 3}$ & $\mathbf{4 0 0 , 1 7 0 , 0 9 4 , 7 1 4}$ & $\mathbf{5 0 0 , 8 6 6 , 8 7 5 , 0 2 3}$ & $\mathbf{4 6 8 , 7 9 6 , 3 6 7 , 9 7 0}$ \\
\hline Belanja Langsung & & & & & \\
\hline a. Belanja Pegawai & - & - & - & - & \\
\hline b. Belanja Barang dan Jasa & 92.138 .431 .294 & 113.707 .185 .641 & $101.331 .585 .568,00$ & 141.340 .842 .371 & 201.765 .811 .877 \\
\hline c. Belanja Modal/Pembangunan & 257.833 .471 .525 & 268.747 .105 .119 & $185.360 .962 .287,67$ & $312,352,486,391$ & 293.930 .004 .267 \\
\hline Jumlah Belanja Langsung & $\mathbf{3 4 9 , 9 7 1 , 9 0 2 , 8 1 9}$ & $\mathbf{3 8 2 , 4 5 4 , 2 9 0 , 7 6 0}$ & $\mathbf{2 8 6 , 6 9 2 , 5 4 7 , 8 5 5 . 6 7}$ & $\mathbf{4 5 3 , 6 9 3 , 3 2 8 , 7 6 2}$ & $\mathbf{4 9 5 , 6 9 5 , 8 1 6 , 1 4 4}$ \\
\hline
\end{tabular}

Sumber : Realisasi APBD Kabupaten Jayawijaya: Data Diolah, 2015

Pada sisi Belanja Tidak Langsung, dimana terjadi penurunan belanja yaitu pada tahun 2014 dari tahun-tahun sebelumnya dengan persentase terendah yaitu $48,60 \%$ dibanding empat tahun sebelumnya. 
Tabel 17

Rasio Belanja Tidak Langsung dan Belanja Langsung Terhadap Total Belanja Daerah Kabupaten Jayawijaya Tahun 2010 - 2014

\begin{tabular}{|c|c|c|c|c|c|}
\hline \multirow{2}{*}{$\begin{array}{c}\text { Tahun } \\
\text { Anggaran }\end{array}$} & \multicolumn{3}{|c|}{ Uraian } & \multicolumn{2}{|c|}{ Rasio } \\
\hline & $\begin{array}{c}\text { Belanja Tidak } \\
\text { Langsung }\end{array}$ & $\begin{array}{c}\text { Belanja } \\
\text { Langsung }\end{array}$ & $\begin{array}{c}\text { Total Belanja } \\
\text { Daerah }\end{array}$ & BTL & $B L$ \\
\hline 2010 & $271,132,567,858$ & $349,971,902,819$ & $618,775,520,677$ & $43,81 \%$ & $56,55 \%$ \\
\hline 2011 & $346,340,357,943$ & $382,454,290,760$ & $728,794,684,703$ & $47,52 \%$ & $52,47 \%$ \\
\hline 2012 & $400,170,094,714$ & $286,692,547,855$ & $686,862,642,570$ & $58,26 \%$ & $41,73 \%$ \\
\hline 2013 & $500,866,875,023$ & $453,693,328,762$ & $954,558,203,785$ & $52,47 \%$ & $47,52 \%$ \\
\hline 2014 & $468,796,367,970$ & $495,695,816,144$ & $964,538,017,453$ & $48,60 \%$ & $51,39 \%$ \\
\hline & & & Rata - Rata & $50,13 \%$ & $49,93 \%$ \\
\hline
\end{tabular}

Sumber: Realisasi APBD Kabupaten Jayawijaya: Data Diolah, 2015

Kemudian pada sisi belanja langsung terjadi kenaikan pada tahun 2010 dengan persentase dan tahun 2011 dengan persentase, selanjutnya kembali terjadi penurunan pada tahun 2012 dengan persentase $41,73 \%$ dan tahun 2013 dengan persentase $47,52 \%$ dari dua tahun sebelumya.

Dari rasio antara Belanja Tidak Langsung dan belanja langsung Pemerintah Kabupaten Jayawijaya tahun 2010-2014, dari total anggaran belanja daerah lebih besar dialokasikan untuk Belanja Tidak Langsung atau Belanja Operasional seperti Belanja Pegawai, Belanja Bunga, Belanja Subsidi Belanja Hibah, Belanja Bantuan Social, Belanja Bagi Hasil, Belanja Keuangan dan Belanja Tidak Terduga dengan persentase $50,13 \%$ dari pada Belanja Langsung dengan persentase $49,93 \%$. Angka pada Belanja Tidak Langsung ini meningkat kerana selama lima tahun tren pertumbuhan Belanja Pegawai masih mendominasi pos-pos dalam anggaran Belanja Tidak Langsung tersebut, sedangkan pada belanja langsung didominasi oleh belanja pembangunan atau belanja pembangunan.

Jumlah ini jauh lebih besar dari persentase yang digunakan untuk anggaran Belanja Modal yang hanya rata-rata 33,74 \% dari total belanja 
daerah Kabupaten Jayawijaya. tersebut digunakan untuk: belanja tanah, belanja peralatan dan mesin, belanja bangunan dan gedung, belanja jalan, irigasi dan jaringan, serta belanja aset tetap lainnya. Dalam rencana maupun realisasi belanja daerahnya lebih besar porsinya pada belanja Tidak Langsung sedangkan untuk penopang pelayanan publik dan penopang ekonomi, seperti infrastruktur, irigasi dan aset lainnya yang termasuk belanja modal masih rendah.

Dengan demikian dapat disimpulkan bahwa Pemerintah Kabupaten Jayawijaya berdasakan kriteria penilaian kinerja keserasian belanja yang dikeluarkan oleh Tim Litbang Depdagri-Fisipol UGM, 1991 dikatakan "Cukup Serasi" dari rata-rata belanja Tidak Langsung dan Belanja Langsung dengan persentase rata-ratanya $50,13 \%$ dan $49,93 \%$.

\section{Analisis Efektivitas Belanja}

Dilihat dari persentase hasil perhitungan rasio ini, pemerintah Kabupaten Jayawijaya telah efektif dalam merealisasikan anggaran belanjanya, karena terlihat kesemua persentase rata-rata $92,94 \%$ dari tahun 2010-2014. Tingkat efektivitas anggaran terendah terjadi pada tahun 2013 dan 2014, hal tersebut dikarenakan pengeluaran biaya Pemerintah Kabupaten Jayawijaya untuk belanja pada tahun 210-2011 mendekati angka yang dianggarkan.

Pemerintah daerah Kabupaten Jayawiajaya telah melakukan efektivitas belanja, hal ini terlihat dari total rata-rata belanja daerahnya selama tahun 2010-2014 hampir mendekati angka 1 atau 100\% atau dengan kata lain penyerapan/ daya serap anggaran belanja selema periode tersebut sudah berjalan sesuai dengan yang direncanakan. Hal ini menunjukan kinerja efektivitas belanja daerah dikatakan cukup efektif. 


\section{Tabel 17}

Efektivitas Belanja Daerah Kabupaten Jayawijaya

Tahun 2010 - 2014

\begin{tabular}{|c|r|c|c|}
\hline Tahun & Anggaran Belanja & $\begin{array}{c}\text { Realisasi } \\
\text { Belanja }\end{array}$ & $\begin{array}{c}\text { Rasio Efektivitas } \\
\text { (\%) }\end{array}$ \\
\hline 2010 & 657.025 .555 .829 & 618.775 .520 .677 & $94,17 \%$ \\
\hline 2011 & 759.583 .804 .386 & 728.794 .648 .703 & $95,94 \%$ \\
\hline 2012 & 738.567 .678 .369 & 686.862 .642 .569 & $92,99 \%$ \\
\hline 2013 & 1.048 .936 .074 .075 & 954.558 .203 .785 & $91,00 \%$ \\
\hline 2014 & 1.064 .481 .116 .328 & 964.538 .017 .453 & $90,61 \%$ \\
\hline \multicolumn{3}{|c|}{ Rata - Rata } & $\mathbf{9 2 , 9 4 \%}$ \\
\hline
\end{tabular}

Sumber : Realisasi APBD Kabupaten Jayawijaya: Data Diolah, 2015

Dengan demikian, dari tabel perhitungan diatas terlihat bahwa berdasarkan criteria penilaian kinerja efektivitas yang ditetapkan Tim Litbang Depdagri-Fisipol UGM, maka kinerja efektivitas belanja daerah Pemerintah Kabupaten Jayawijaya dikategorikan "Efektif" yang dibuktikan dengan rasio efektivitas pada tahun 2010 - 2014 dengan persentase rata-rata $92,94 \%$

Namun pengeluaran belanja pada setiap pemerintah daerah juga mesti dilihat tergantung dengan dinaminasi kegiatan pembangunan dan besarnya kebutuhan investasi yang diperlukan untuk mencapai pertumbuhan yang ditargetkan. Sebuah pemda dikatakan telah melakukan efektifitas, maka perlu dipertimbangkan juga apa-apa saja yang menjadi penyebab ataupun menjadi dampak apabila terjadi kenaikan dan juga penurunan pada belanja daerah. Pemda tidak dapat terlalu hemat, hanya kerena total belanjanya sudah membengkak, kemudian pada tahun berikutnya menurunkan belanjanya tetapi tidak mempertimbangkan apa-apa yang di butuhkan sebagai kebutuhan primer bagi pembangunan untuk mengembangkan daerah tersebut. 


\section{Analisis Overlay Belanja}

Analisis ini digunakan untuk mengkomparasi dan mengukur skor kinerja berdasarkan rasio-rasio belanja yang telah diukur sebelumnya. Skor ditetapkan berdasarkan penjumlahan tanda (+) dan (-) dari masingmasing indikator rasio yang telah diukur dahulu. Jika skor kinerja bertanda $(+)$ berarti kinerja belanja dikatakan baik. Sebailknya jika skor kinerja bertanda (-) dapat dikatakan kinerja Belanja tidak baik.

Tabel 18

Analisis Kinerja Belanja Kabupaten Jayawijaya Tahun 2010 - 2014

Berdasarkan Analisis Overlay

\begin{tabular}{|c|c|c|c|c|c|c|}
\hline \multicolumn{9}{|c|}{ Uraian } & \multicolumn{2}{|c|}{} \\
\hline $\begin{array}{c}\text { Tahun } \\
\text { Anggaran }\end{array}$ & $\begin{array}{c}\text { Analisis } \\
\text { Varians }\end{array}$ & $\begin{array}{c}\text { Analisis } \\
\text { Pertumbuhan }\end{array}$ & $\begin{array}{c}\text { Analisis } \\
\text { Keserasian }\end{array}$ & $\begin{array}{c}\text { Analisis } \\
\text { Efektivitas }\end{array}$ & Skor & $\begin{array}{c}\text { Kriteria } \\
\text { Kinerja }\end{array}$ \\
\hline 2010 & + & & + & + & 3 & Baik \\
\hline 2011 & + & + & + & + & 4 & Baik \\
\hline 2012 & + & + & - & + & 2 & Baik \\
\hline 2013 & + & + & - & + & 2 & Baik \\
\hline 2014 & + & + & - & + & 2 & Baik \\
\hline
\end{tabular}

Sumber : Data Diolah, 2015

Dari analisis tabel diatas, sepanjang periode 2010-2014 berdasarkan analisis overlay, terindikasi bahwa kinerja anggaran belanja daerah Kabupaten Jayawijaya selama periode tersebut termasuk dalam kategori "baik". Hasil penelitian ini tidak sama dengan atau dengan kata lain menolak hipotesis sementara sebelumnya yang menyatakan kinerja belanja daerah Kabupaten Jayawijaya termasuk dalam kategori cukup baik.

Kondisi atau hal tersebut ditunjang oleh pertumbuhan belanja daerah Kabupaten Jayawijaya yang selalu meningkat dan efektivitas belanja yang selalu masuk dalam kategori efektif. 


\section{KESIMPULAN DAN SARAN}

\section{Kesimpulan}

Berdasarkan hasil analisis dan pembahasan maka ditarik kesimpulan sebagai berikut:

a. Kinerja Pendapatan Pemerintah Daerah Kabupaten Jayawijaya selama tahun anggaran 2010 - 2014 dilihat dari analisis Overlay di kategorikan "Tidak Baik". Hal ini dibuktikan dengan hasil analisis overlay secara agregat yang ditunjukan dengan adanya tingkat kemandirian keuangan daerah yang dililai sangat kurang, tingkat ketergantungan keuangan daerah yang sangat tinggi pada dana pusat (transfer) serta derajad desentralisasi fiskal daerah yang dikategorikan sangat kurang yang walaupun dilihat dari analisis varian anggaran dan tren pertumbuhan pendapatan dapat dinyatakan cukup baik.

b. Kinerja Belanja Pemerintah Daerah Kabupaten Jayawijaya Selama tahun anggaran 2010 - 2014 dilihat dari Analisis Overlay di kategorikan "Baik". Hali ini ditunjang atau dibuktikan dengan hasil analisis terhadap beberapa rasio belanja seperti varians belanja daerah yang dinilai baik, pertumbuhan belanja daerah yang dikategorikan baik dan keserasian antara belanja langsung dan belanja tidak langsung yang dinyatakan cukup serasi serta kinerja efektivitas pelaksanaan belanja daerah yang dikatergorikan efektif.

\section{Saran}

Berdasarkan kesimpulan dalam kajian ini, maka saran atau rekomendasi sebagai berikut:

a. Pemerintah Daerah Kabupaten Jayawijaya perlu lebih giat atau berupaya lagi untuk dapat meningkatkan penerimaan Pendapatan Asli Daerah (PAD) melalui intensifikasi dan ekstensifikasi potensipotensi atau sumber-sumber yang sudah ada maupun menggali potensi-potensi/sumber-sumber yang baru dalam rangka upaya 
peningkatan kemandirian fiskal daerah, mengurangi tingkat ketergantungan serta meningkatkan desentralisasi fiskal pemerintah daerah;

b. Pemerintah Kabupaten Jayawijaya perlu meningkatkan prestasi dengan upaya peningkatan kinerja dalam pelaksanaan anggaran belanja daerah dalam rangka penyelenggaraan urusan pemerintahan, pembangunan dan pelayananan kepada masayarakat.

Perlu meningkatkan pendidikan dan latihan dalam rangka peningkatan kapasitas dan profesionalitas aparatur dalam bidang pengelolaan keuangan atau anggaran daerah.

\section{DAFTAR PUSTAKA}

Adhim, Mohammad, 2008. Analisis Kinerja Anggaran Pemerintah dan Kaitannya degan Perekonomian Daerah di Kabupaten Sarolangun (Thesis S2). Universias Negeri Jambi.

Bastian, Indra, 2006. Akuntasi Sektor Publik : Suatu Pengantar . Erlangga, Jakarta.

Erlina, Sri Mulyadi, 2007. Metode Penelitian Bisnis Untuk Akuntasi dan Manajemen . USU Press, Medan.

Halim, Abdul, 2004. Akuntasi Keuangan Daerah, Edisi Revisi, Salemba Empat, Jakarta

Mahmudi, 2007. Manajemen kinerja Sektor Publik. UUP STIM YKPN, Yokyakarta

Mardiasmo, 2005. Akuntasi Sektor Publik Andi. Yokyakarta.

Marizka, Addina. 2009. Analisis Kinerja Pengelolaan anggaran Pendapatan dan BelanjaDaerah Pemerintah Kota Medan(Skripsi S1). Universitas Sumatera Utara.

Nordiawan, Dedi, 2006. Akuntasi Sektor Publik, SAlemba Empat, Jakarta.

Rosalina, Eka. 2008. Analisis Kinerja Pengelolaan Keuangan Daerah Anggaran Pendapatan dan Belanja Daerah ( Studi Kasus di Provinsi Sumatra Barat. ( Thesis S2). Universitas Gadjah Mada. 
Sugiyono, S., L.T. Agus, dan Hariyandi. 2005. Penanggaran Sector Public, Pedoman Praktis, Penyusunan, Pelaksanaan Dan Pertanggungjawaban APBD ( Berbasis Kinerja).

Republic Indonesia, Undang-Undang Nomor 17 Tahun 2003 Tenang Keuangan Negara.

Badan Litbang Depdagri RI dan Fisipol UGM,1991, Pengukuran Kemampuan Keuangan Daerah Tingkat II Dalam Rangka Otonomi Daerah Yang Nyata dan Bertanggung Jawab, Jakarta 